【総説】

\section{音楽療法における評価 \\ Evaluation in the Music Therapy}

\author{
板東 浩 ${ }^{1, *}$ ，佐治順子 ${ }^{2}$ \\ Hiroshi BANDO ${ }^{1, *}$, Nobuko SAJI ${ }^{2}$ \\ 1 日本音楽療法学会評議員, 国際交流委員 \\ 2 日本音楽療法学会理事, 国際交流委員長
}

\section{【要 旨】}

音楽療法は広義（音楽健康法）と狭義（治療目的）に 大別でき，後者では実践を通じて経時的に観察し評価 を行う. 頻度が高い高齢者対象のセッションでは, 長 期目標として，健常者には心身の諸機能低下を予防し て認知症を回避し，認知症や脳血管障害者には諸機能 低下を改善および維持し, 重篤な病態や緩和ヶアの患 者には QOL の向上を目指す。評価法として，板東法 では感覚, 行動, ADL/QOL など 20 項目を, 佐治法で は積極性, 持続性, 協調性, 情緒性, 知的機能, 歌唱 演奏，手の操作，歩行式，身体の円滑さ，返答など 10 項目を評価する．松井は音楽療法診断表（一般用）と 音楽療法評価表（老人用）をまとめ, 北本 (卯辰山) 式，岡崎・門間式，赤星式などもある. 日本音楽療法 学会認定の音楽療法士が増加し, 2009 年 3 月には東 京で第 1 回アジア音楽療法シンポジウムも開催され た. 音楽療法は補完代替医療の中で他の療法との併用 も試みられ, さらに重要となりつつある.

【キーワード】

音楽療法, 評価, 音楽療法士, アジア音楽療法シンポ ジウム, 補完代替医療
はじめに

近年，音楽療法 (music therapy) は，補完代替医療の中 でも重要な位置を占め注目されてきている。筆者らは, 従来音楽療法の啓発や実践研究に携わって扣り ${ }^{1-3)}$, 板東 は, 2009 年 9 月に開催される第 9 回日本音楽療法学会学 術大会4) で大会長を務めることとなった。 音楽療法は, 医療や福祉を主としながら，教育や芸術文化などにも密 接に関わっており，今後の方向性を考慮する重要な時期 にも差し掛かっている，そのため，補完代替医療に関与 している方々にも, 音楽療法により一層理解を深めてい ただきたいと考えている

本稿では，まず本邦に打ける音楽療法の位置づけや経 緯に触れ，引き続き実践現場で重要な音楽療法効果に対 する評価の問題を解説し，最後に佐治が委員長を務める 日本音楽療法学会国際交流委員会が去る2009年3月に開 催したアジア地区音楽療法シンポジウムなど最近の動向 について報告したい.

\section{1. 補完代替療法における音楽療法の位置づけ}

音楽療法の位置づけは多面的である．補完代替医療の 中に打ける標準的な分類を表 1 に示した. この中で，音 楽療法は心身の作用といら範疇に入る. 芸術療法の中に, 音楽療法が含まれると考劣ても差し支えない，近年は， 音楽療法と他の療法を組み合わせる傾向もみられる.

他に，音楽療法を広義（音楽健康法），あるいは狭義 （治療を目的とした療法）に捉えて，大別することもでき る. 前者は対象が健常者であり，音楽を楽しみレクレー ション的に音楽を活用するものである. 特に，音楽の効

表 1 補完代替医療に含まれる療法

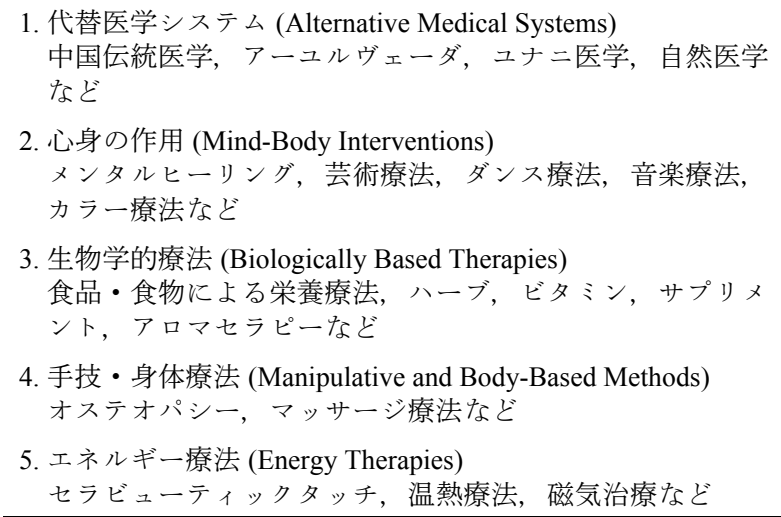


果を検討する必要はない。

一方，後者では，対象は何らかの健康問題を有する患 者である. 音楽は治療の一法として使用される.つまり, 心身の改善・回復の目的や目標を設定して, 音楽療法の 実践（セッション）を行う。従って, 音楽療法前後の症 状を経時的に観察記録し, 効果の程度をきちんと評価す る必要がある，評価の詳細については後述する.

\section{2. 我が国における音楽療法の経緯}

本邦に扮ける音楽療法の経緯について，簡単に触れて おく. 欧米と比較して, 日本の音楽療法の発展は著しく 遅れた，その一因として，日本の音楽界では音楽の技能 を磨き，その成果を競い合ら重要性が強調されてきたこ とが挙げられる，音楽を愉しむよりも，むしろ高度な演 奏レベルや芸術性の習得が重要視された. その例として, 環境音楽 BGM が導入された際には, 仕事中に音楽を聴 く態度が問題で，音楽とは精神を集中して聴くべきもの だとされた。実際，我が国の産業界でも，音楽を聴きつ つ仕事を行ならのは不適切との見解もあった。つまり， 日本の音楽療法の発展には, このよらな音楽に対する文 化的背景が少なからず影響していると考兄られる.

我が国で音楽療法が認識されたきっかけとして, 戦後 米国で出版されたランディンとボドルスキー5)の著書が 挙げられる。また，1960年代に世界的音楽療法界の権威 ジュリエット・アルバン女史の来日で，音楽療法の実践 的効果が注目されるようになった. 1969 年には芸術療法 研究会 (現芸術療法学会) が, 1986 年には日本バイオ ミュージック研究会（後の日本バイオミュージック学 会), 1994 年には臨床音楽療法協会が設立された.

我が国に打ける資格認定音楽療法士の育成や音楽療法 のさらなる展開のため, 後二者の学会が 1995 年に合併し て日本音楽療法連盟（日野原重明理事長）が発足し, 2001 年に日本音楽療法学会と改名され, 全国組織として現在 に至っている. 2002 年より毎年 1 回全国学術大会時に総 会が開催され，3 年に 1 回評議員・理事役員選挙も実施さ れている. 他に各支部大会, 研修・講習会なども開催さ 孔， 2009 年 3 月現在，同学会会員はすでに 6000 人を超 光, 飛躍的発展がみられる.

\section{3. 高齢者に対するセッション}

音楽療法を受ける対象者は, クライアントと呼ばれる。 本邦でのクライアントは, 高齢者（健常者, 認知症患者, 脳卒中患者等）から若年者（知的障害児，心身の疾病患 者等）まで多岐にわたる，特に，心理的精神的な疾病を
有する患者の場合は，福祉や行政関係などの支援も含ま れる。これらの中でセッション頻度が最も高いのは，さ まざまな施設に入所している高齢者である.

高齢者に対するセッションの場合, 症状の改善に適し た目標を設定した上で臨むことが，肝要である（表 2）。 また，緩和ケアも含めた高齢者に打いては，生活の質 (QOL) の向上も重要な目標となる（表 3).

2008 年版の高齢者白書によると年，総人口が減少する 中, 高齢者が増加することにより高齢化率は上昇を続け, 2013 年には 4 人に 1 人が, 2035 年には 3 人に 1 人が 65 歳以上の高齢者になると推計されている。，一方，後期高 齢者人口は増加を続け，2017 年には前期高齢者を上回 り，その後も増加傾向が続くものと見込まれている。 そ して加齢と共に認知症有病率が上昇し，「65 歳以上の高 齢者人口の認知症有病率は, 2001 年で 7.3\%だったが, 2021 年には，9.3\%になるであろら」とされる77.

加齢とともに心身の諸機能低下は，不可逆的現象であ る. そこで，認知症を回避しいつまでも元気で過ごすた め，高齢者のセッションでは，次の三つの長期目標の中 から選択する。そして，その目標を実現するために，さ らに短期目標を設定する。

長期目標の第一は，主に健常高齢者に対して与只られ るもので，心身の諸機能低下を「予防」し，認知症にな らないようにする，第二は，主に中軽度認知症あるいは 脳血管障害者なぞに対するもので, 諸機能低下を「改善・ 維持」する．第三は，終末期の重度認知症高齢者または

表 2 高齢者に対する音楽療法の目標

\begin{tabular}{ll}
\hline 身体 & 運動能力の維持・向上・感覚訓練 \\
& 不適応行動の減少 \\
\hline 精神 & 長期記憶や回想への刺激 \\
& 短期記憶や認知力の向上 \\
& 言語能力の向上 \\
& 心身両面の発散 \\
\hline 心理 & リラクゼーションの促進 \\
& ストレスの軽減 \\
& 自己尊絾の回復 \\
& 痛みや悩みから気分転換 \\
\hline 対人 & 他者との交流への援助 \\
& 楽しさ, 遊び, ユーモアの場の提供 \\
& 余暇活動における援助 \\
& בミュニラーション能力の向上 \\
\hline
\end{tabular}

表 3 音楽療法による $\mathrm{QOL}$ の向上

心理的変化孤独感, 自信, 動機ら゙け，充足感

身体的変化身体機能の維持, リハビリテーション

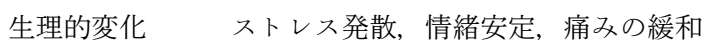

社会的変化対人関係, 社会との交流

哲学的変化霊的 (spiritual), 受容, 明日への希望 
緩和ケア患者に対し，もはや諸機能低下は免れないが, 「QOL の向上」を目指するのである.

また，音楽療法には，個人セッションと集団セッショ ンがあり, その選択は音楽療法士によって判断される. 一般に集団になじめず，個別対応が必要な場合は，個人 セッションが推奨される. 特に高齢者の場合, 最終的に は集団セッションの中でもコミュニケーションが成立で

表 4 セッションで目的に応じて活用できる曲目の例（文献 8 より一部抜粋)

\begin{tabular}{|c|c|}
\hline $\begin{array}{l}\text { リバイバル\&カバー } \\
\text { 世代幅が広く, 人気が } \\
\text { あります }\end{array}$ & 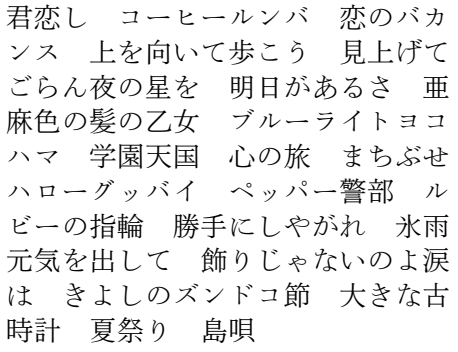 \\
\hline $\begin{array}{l}\text { 異国情緒 } \\
\text { 日本語以外の言葉は, } \\
\text { ラララで歌いましょ } \\
\text { う. }\end{array}$ & 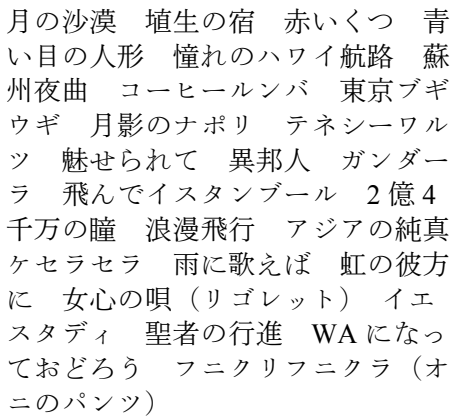 \\
\hline
\end{tabular}

き，社会性が維持されることが目標となる.

実際のセッションでよく使用される楽曲は，高齢者の 場合活とんぞが幼い頃，あるいは若い頃よく聞いたり 歌ったりしたことのある童謡, 唱歌, 歌謡曲である ${ }^{8)}$. 機 能別の楽曲例として，表 4 をあげておこう．既に記憶の 中にある楽曲を介して，クライエントの脳活動を活発に し, 自発的発現を促寸方法は回想療法と呼ばれ，高齢者 のセッションでよく用いられる。この継続的介入は有効 な脳刺激となり，クライエントを自発的な発語や歌唱・ 演奏意欲，生きがい几導くとされる3,9)。

\section{4. 評価が重要ポイント}

クライエントの症状改善，あるいは QOL 向上といら 目標を持つ狭義の音楽療法では, クライエントに対する 査定（アセスメント）に基づいたセッション目標に対し て，どの程度達成されたのか，きちんとした評価が必要 となる. その理解のため, 頻度が高い高齢者の例を示す。

症 例 : 72 歳, 男性

主 訴: 生活意欲の低下と不安定な QOL/ADL

現病歷: 生来健康で著疾はなかった. 70 歳ごろから生 活に対する意欲がやや低下し始め, 72 歳で高齢者施 設へ入所. 2 力月後ごろから, 次第に生活意欲の低 下や不安定な QOL/ADL がみられ，4 カ月後に増悪 してきた。

家族歴 : 特筆すべきことはない

表 5 音楽介護評価表（板東作成）

\begin{tabular}{|c|c|c|c|c|c|}
\hline 1. 食事 & $\square$ 自立 & $\square$ 観察誘導 & $\square$ 一部介助 & $\square$ 広範介助 & $\square$ 全面介助 \\
\hline 2. 排泄 & $\square$ 自立 & $\square$ 観察誘導 & $\square$ 一部介助 & $\square$ 広範介助 & $\square$ 全面介助 \\
\hline 3. 着脱 & $\square$ 自立 & $\square$ 観察誘導 & $\square$ 一部介助 & $\square$ 広範介助 & $\square$ 全面介助 \\
\hline 4. 入浴 & $\square$ 自立 & $\square$ 観察誘導 & $\square$ 一部介助 & $\square$ 広範介助 & $\square$ 全面介助 \\
\hline 5. 歩行 & $\square$ 自立 & $\square$ 観察誘導 & $\square$ 一部介助 & $\square$ 広範介助 & $\square$ 全面介助 \\
\hline 6. 移動 & $\square$ 自立 & $\square$ 観察誘導 & $\square$ 一部介助 & $\square$ 広範介助 & $\square$ 全面介助 \\
\hline 7. ベッド上動作 & $\square$ 自立 & $\square$ 観察誘導 & $\square$ 一部介助 & $\square$ 広範介助 & $\square$ 全面介助 \\
\hline 8. 個人衛生 & $\square$ 自立 & $\square$ 観察誘導 & $\square$ 一部介助 & $\square$ 広範介助 & $\square$ 全面介助 \\
\hline 9. 視力 & $\square$ 正常 & $\square$ 十分 & $\square$ 軽度障害 & $\square$ 中等度 & $\square$ 高度障害 \\
\hline 10. 聴力 & $\square$ 正常 & $\square$ 十分 & $\square$ 軽度障害 & $\square$ 中等度 & $\square$ 高度障害 \\
\hline 11. 言語・会話 & $\square$ 正常 & $\square$ 十分 & $\square$ 軽度障害 & $\square$ 中等度 & $\square$ 高度障害 \\
\hline 12. 理解 - 痴呆 & $\square$ 正常 & $\square$ 十分 & $\square$ 軽度障害 & $\square$ 中等度 & $\square$ 高度障害 \\
\hline 13. 異常行動 & ロなし & $\square$ 既往あり & 口軽度あり & $\square$ 中等度 & $\square$ 高度あり \\
\hline 14. 不潔行動 & 口なし & 口既往あり & 口軽度あり & $\square$ 中等度 & 口高度あり \\
\hline 15. 不穏 - 興奮 & ロなし & 口既往あり & 口軽度あり & $\square$ 中等度 & 口高度あり \\
\hline 16. 生活の意欲 & $\square$ 正常 & $\square$ 十分 & $\square$ 軽度障害 & $\square$ 中等度 & $\square$ 高度障害 \\
\hline 17.レクと運動 & $\square$ 正常 & $\square$ 十分 & $\square$ 軽度障害 & $\square$ 中等度 & $\square$ 高度障害 \\
\hline 18. 職員との交流 & $\square$ 正常 & $\square$ 十分 & $\square$ 軽度障害 & $\square$ 中等度 & $\square$ 高度障害 \\
\hline 19. 患者間の交流 & $\square$ 正常 & $\square$ 十分 & $\square$ 軽度障害 & $\square$ 中等度 & $\square$ 高度障害 \\
\hline 20. 医師との交流 & $\square$ 正常 & $\square$ 十分 & $\square$ 軽度障害 & $\square$ 中等度 & $\square$ 高度障害 \\
\hline
\end{tabular}


経 過：本例に対して，代替療法の一つである音楽療 法セッションを実施した．対象者は本例を加えた同 施設に入所している高齢者 20 例である. 方法は集団 的音楽療法セッションであり, 頻度は週に 1 回 1 時 間. 内容は音楽や言葉によるコミュニケーションに 加光, 受動的な聴取療法や, 能動的な歌唱や打楽器 を用いた演奏療法なども含まれる。効果の判定は セッション前と実施後 3 カ月後の時点で, QOL/ADL に対して，板東らが提唱した「音楽評価表」による 評価を 5 段階で行った (表 5) ${ }^{10)}$. その結果, セッ ション前に比して後には, 着脱, 入浴, 歩行, 移動, 聴力, 言語・会話, 理解, 生活意欲, レクと運動, 職員・患者・医師との交流などのファクターに改善 が認められた（図1）。

なお，この評価表の項目と領域については，1８）は ADL を, 9〜12) は感覚を，13〜15) は行動を，16２0) は QOL の評価を示している.さらに，対象者が回答できる 場合は長谷川式スケールを用いる. 30 点満点で, 21 点以 上が非痴朵，20点以下が痴呆である. 回答できない場合 には $\mathrm{N}$ 式老年者用精神状態尺度（NM スケール）を用い る．患者の身辺整理，意欲，会話，記銘，見当識につい てスタッフが 10 点ずつ評価し, 正常（50-48 点），境界 (47-43 点), 軽度痴朵 (42-31 点), 中等度痴呆 (30-17

\section{音楽療法前後の検討}

\begin{tabular}{|c|c|}
\hline 1. 食事 & $\square \square$ 甲 $\square$ \\
\hline 2. 排泄 & 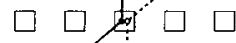 \\
\hline 3. 着脱 & 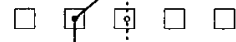 \\
\hline 4. 入浴 & 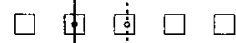 \\
\hline 5. 歩行 & $\square$ 申育口 $\square$ \\
\hline 6. 移動 & $\square$ 皮高口 $\square$ \\
\hline 7. ベッド上動作 & $\square \square \square \square$ \\
\hline 8. 個人衛生 & $\square \square \square$ 问 $\square$ \\
\hline 9. 視力 & $\square \square<\square \square$ \\
\hline 10. 恵力 & $\square \square 申 \square \square$ \\
\hline 11. 言語·会話 & $\square \square 申 \emptyset 口$ \\
\hline 12. 理解 - 痴呆 & 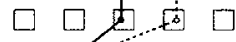 \\
\hline 13. 異常行動 & $\square \square \square \square$ \\
\hline 14. 不潔行動 & $\square$ 軎 $\square \square \square$ \\
\hline 15. 不稳・興奮 & $\square \square$ \\
\hline 16. 生活の意欲 & $\square \square$ 曰 $\square$ \\
\hline 17. レクと運動 & $\square \square$ 内口 \\
\hline 18. 職員との交流 & $\square \varnothing \square \sqrt{\circ} \square$ \\
\hline 19. 患者間の交流 & $\square$ 車 $\square \square \square$ \\
\hline 20. 医師との交流 & $\square \square \square \square$ \\
\hline
\end{tabular}

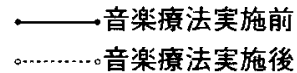

図 1 音楽療法前後に扔汀る検討例
点), 重症痴呆（16-0 点）と評価する.

\section{5. 音楽療法の分野における評価法}

ひきつづき，音楽療法の領域における特質を加味した 評価法について記す.

佐治は, 音楽療法セッションに参加した約 70 名の施設 入居者（平均 $82.1 \pm 3.3$ 歳）のセッション前後の行動查定 々観察記録を通して，高齢者の音楽療法分野に和汀る評 価を，次の 10 項目で 4 段階評価を「佐治音楽療法評価 表」として提唱した（表 6) ${ }^{11)}$. その項目は，積極性，持 続性, 協調性, 情緒性, 知的機能, 歌唱演奏, 手の操作, 歩行，身体の円滑さ，返答である。

松井 ${ }^{12)}$ は従来の音楽療法研究での評価を, 音楽療法診 断表（一般用）と音楽療法評価表（老人用）としてまと めているが，佐治は後者の音楽療法評価表（老人用）を， 自ら改訂版として新たに作成し，セッション評価の一指 針として使用した ${ }^{3)}$. 他に高齢者の音楽療法評価表に, 北 本 (卯辰山式) 評価法 ${ }^{13)}$ や岡崎・門間音楽療法評価表 ${ }^{14)}$, 赤星養育評価法 ${ }^{15)}$ などがある.

佐治音楽療法評価法では，対象者の中に重度認知症高 齢者が含まれるため，できるだけ小さな行動変化までる 汲みとる必要があるための改訂である．主な変更点は以 下の通りである.

1) 簡潔な表現とした：たとえば A. 積極性 1.「指示され ても回避的で」を，「回避的で」に短縮した.

2) 特記すべき行動を拾いあげるために，新たな項目を追 加した：これは症状が悪化しても，七ッションの経過 とともに，たとえば「歌唱・演奏」や「自分の名前に 返答する」に変化がみられたので追加項目にした，特 に音楽発現が見觉ない，とら光難い重度認知症高齢者 でも，自分の名前には反応できた。この返答時の表情 が当日のクライエントの症状を察知する上で重要で あった。

3）表現方法を変えた：たと兊ば A. 積極性 2.「消極的で あるが，支持された活動はやろらとする」を，「参加し ないが，関心を示す（目で追う）」と変更した。「目で 追う」行動は，まだ「活動はやろらとする」ところま でいかない中間的発現行動であるが，次のやろらとす る活動に発展する可能性の高い前行動として, 認知症 高齢者にとって注目すべき変化であるからである.

実際に当評価表を適用した事例を，パーキンソン病高 齢者の音楽療法のセッション効果（図 2) ${ }^{16}$ ) で示そう.

症 例 : 3 名の PD 患者: 対象者 $\mathrm{a}$ は 75 歳女性, ヤ一 ル I 段階，罹病約 6 年. 対象者 $\mathrm{b}$ は 75 歳女性，ヤー ル II 段階, 罹病約 5 年. 対象者 $\mathrm{c}$ は 66 歳男性, ヤー 
表 6 佐治音楽療法評価表

\begin{tabular}{|c|c|}
\hline 項目 & 評価（4 段階） \\
\hline A) 積極性 & $\begin{array}{l}\text { 1. 回避的で, まったく参加しない. } \\
\text { 2. 参加しないが, 関心を示す (目でおう). } \\
\text { 3. 側に行くと口を動かし参加する. } \\
\text { 4. 積極的で, 喜んでとりくむ. }\end{array}$ \\
\hline B) 持続性 & $\begin{array}{l}\text { 1. まったくできない. } \\
\text { 2. 短時間なら持続できるが，途中で場を離れる. } \\
\text { 3. 比較的集中して持続できるが，ときに疲れてしまう. } \\
\text { 4. 最初から最後まで集中して持続できる. }\end{array}$ \\
\hline C) 協調性 & $\begin{array}{l}\text { 1. まったくマイペースである. } \\
\text { 2. 他者と協調しようとするが, うまくできない. } \\
\text { 3. 受身的であるが, ときどき協調性が認められる. } \\
\text { 4. 協調的で, ときにリーダーシップもとる. }\end{array}$ \\
\hline D) 情緒性 & $\begin{array}{l}\text { 1. 情緒表現がまったく認められない. } \\
\text { 2. 微かに表現される(目が動くなど). } \\
\text { 3. 働きかければ情緒表現がある. } \\
\text { 4. 感情の表現能力が豊かである. }\end{array}$ \\
\hline E) 知的機能 & $\begin{array}{l}\text { 1. 痴呆症状が顕著である. } \\
\text { 2. 記憶力に問題があるが, ときどき歌詞がでてくる. } \\
\text { 3. 学習がある程度可能であるが, 維持されがたい. } \\
\text { 4. 記憶力がよく, 学習も可能である. }\end{array}$ \\
\hline F) 歌唱·演奏 & $\begin{array}{l}\text { 1. まったくできない. } \\
\text { 2. 目や耳で聴き, 身体が微かに動く. } \\
\text { 3. みんなと一緒であればできる. } \\
\text { 4. 一人で正確にできる. }\end{array}$ \\
\hline G) 手の操作 & $\begin{array}{l}\text { 1. 把握力がなく, 日常生活に支障がある. } \\
\text { 2. 微かに手を動かすことができる. } \\
\text { 3. 把握力はあるが最後まで続かない. } \\
\text { 4.しっかり動かし, リズムに合わせることができる. }\end{array}$ \\
\hline H) 歩行 & $\begin{array}{l}\text { 1. 歩行や移動がまったく不可能である. } \\
\text { 2. 車椅子を使用するが, すこし動ける. } \\
\text { 3. 軽い支持が必要であるが, 移動可能である. } \\
\text { 4. 一人で歩行, 移動できる. }\end{array}$ \\
\hline I) 体や動作の円滑さ & $\begin{array}{l}\text { 1. 体は固く,姿勢の変化もできない. } \\
\text { 2. 物をもち上げたり，運んだりすることは難しく，方向転換にも時間がかかる. } \\
\text { 3. 体のバランスはややとれるが，早い動作は困難. } \\
\text { 4. 体操等はほぼ正確にでき,早足,駆足もある程度できる. }\end{array}$ \\
\hline J) 名前に返答する & $\begin{array}{l}\text { 1. まったく反応しない. } \\
\text { 2. 名前を呼ばれたことがわかり，目が動く. } \\
\text { 3. 名前に行動反応を示す (笑顔など). } \\
\text { 4. 声を出して，はっきりと反する。. }\end{array}$ \\
\hline
\end{tabular}

佐治順子.「認知症高齢者の音楽療法」, 『認知症のリハビリテーション実践マニュアル』, 全日本病院出版社, 66-79, 2005. 表中の F), J) は，松井評価表と大きく変更，および新たに追加した項目である.

ル III 段階，罹病約 15 年である.

主 訴：次第に薬剤量が多くなることへの不安，生活 上でもすくみ現象が見られてきたことから外出や人 と話すことが減少した. 声がかすれてきたことから， 声が出なくなることへの不安がある.

現病歴: 対象者 3 名とも, PD 患者特有の振戦, 姿勢 保持障害，らつ的傾向が認められた. 特に罹病年の 長い対象者 c は, 既に早口で言葉が聞き取れない構 音障害を有していた。

家族歴 : 特筆すべきことはない.
経 過 : 神経難病疾患の一つであるパーキンソン病疾 患であるため， 5 年間の経過の中で，振戦，筋肉の 硬直，すくみ現象など（評価表では，手の操作，歩 行，体の円滑さの項目）は，維持あるいは緩やかな 低下がみられたのに対して，他の項目は評価 4 で維 持された.

図 2 に示した音楽療法評価表の評価結果は, 複数の音 楽セッション関係者（音楽療法士らとセッション参加協 力の看護師）らによる平均評価値 (少数以下は四捨五入) であるが, 音楽は時間芸術の一つであり，また個人によっ 
音楽療法評価表の評価

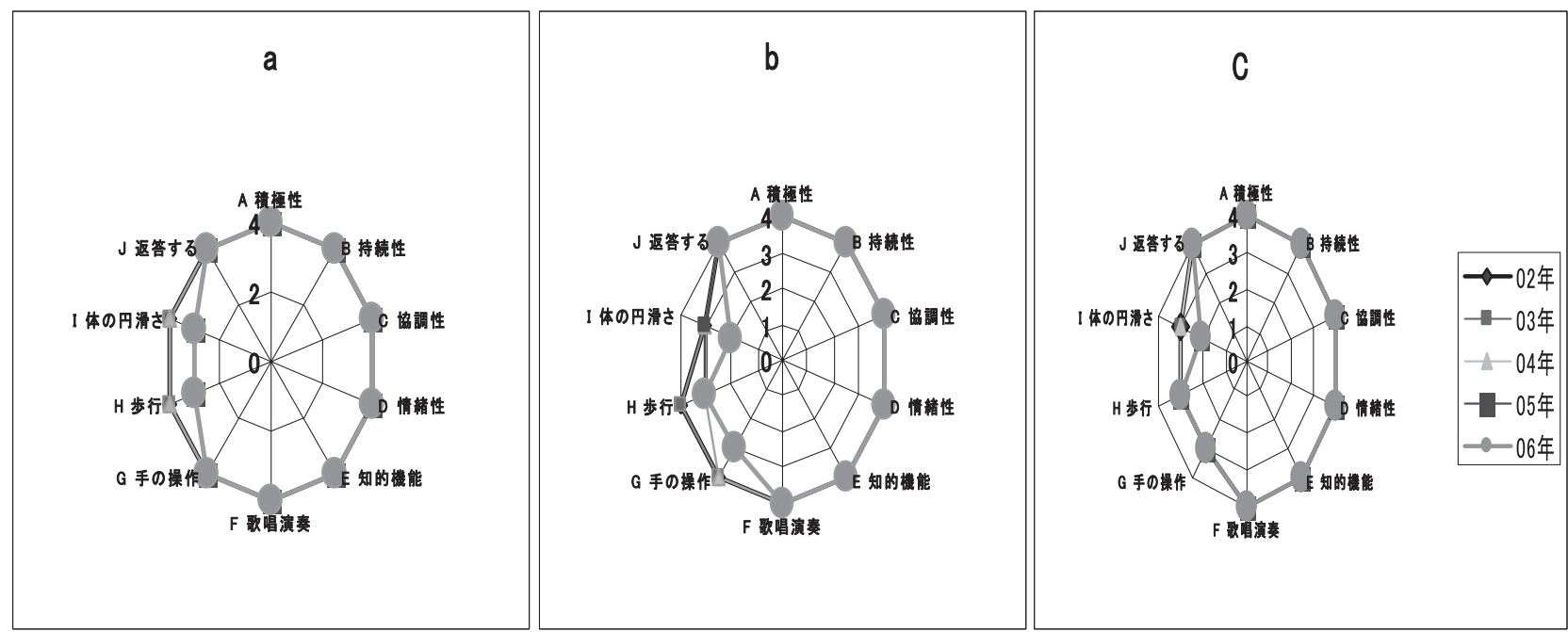

図 2 ステージの異なるパーキンソン患者 3 名の音楽療法効果 ${ }^{16)}$

対象者 a, b , c とも02-06年まで図 A-F, J（積極・協調・情緒性など）は評価 4 を維持できたが，G-H（身体的機能）は経年的に評価が 低下. 特に対象者 $\mathrm{b}, \mathrm{c}$ は I（体の円滑さ）が 5 年目に評価 2 に低下した. 健常対照群は, 10 項目全て評価 4 であった.

従って, 継続的音楽療法は，らつ症状や閉じこもり傾向にある PD 患者に，情緒の安定，協調性，参加の楽しみや積極性など，精神面 に有効な効果が認められる.

て墸好も全く異なるものである。そして抗生物質やステ ロイド薬とは異なり，治療前後の比較を数字で明確に表 すのは難しい，従って，科学性，普遍性，妥当性なぞに も自ずと限界がある。

近年はエビデンスに基づく医療が叫ばれ，音楽療法の 領域でも報告が増えてきた。内分泌的には，音楽聴取で ストレスの際にみられるコルチゾル上昇が抑制された り, 生演奏音楽や好久の音楽の聴取はストレスを軽減さ せるが，一方で嫌いな音楽の聴取はストレスを増加させ るといら ${ }^{17)}$ 。また，テストステロン (T) は短時間のスト レスで上昇し，長期のストレスで減少し，音楽の聴取に 対する T 濃度の変化は男性では低下するが，女性では上 昇するとされる ${ }^{18)}$. 心理面では，音楽に対する影響は， 音楽経験の有無によることが報告されている ${ }^{19}$.

音楽療法と認知症のキーワードでシステマティックレ ビューが行われ，20 年間のオンラインデータベース (PubMed, PsycINFO) を検索し, 313 件から質の高い 74 件 が評価された ${ }^{20)}$. RCT による研究が期待されて和り，不 眠の改善 ${ }^{21)}$ や放射線治療 ${ }^{22)}$ や外科手術での不安の軽減 なぞにも，音楽療法の効果が実証されている.

\section{6. 音楽療法士と最近の動向}

現在，本邦で補完代替医療にかかわる職種には，音楽 療法士 (MT, music therapist)，理学療法士 (PT), 言語療法

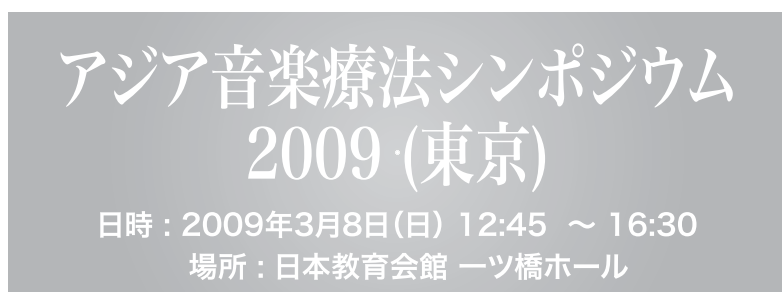

テーマ: アジアにおける音楽療法の実践と教育

パネリスト :
1) ヒョン・ジュ・チョン氏（韓国）
: 梨花女子大学准教授·音桨察法コ一ス主任( $\mathrm{PhD}$ )
2) ブッサコーン・サムロントーン氏 (タイ) : チュラロンコーン大学准教授·応用美術学部長(PhD)
3) スマティ・スンダール氏 (インド)
ナ夕音㝝療法センター名誉会長 $(P h D)$
4) ティアン·ガオ氏 (中国)
音楽療法研究セン夕一准教授·セン夕一長(PhD)
5) パツィ·タン氏 (シンガポール)
シンガポール紷合病院音楽呩法土 $(\mathrm{PhD})$
6) 佐治 順子氏 (日本)
域大学看樭学部教㥅 $(\mathrm{PhD})$

会場：

干 100-0003

東京都千代田区一ツ橋 2-6-2

日本教育会館 ーツ橋ホール

http://www.jec.or.jp

http://www.jec.or.jp/koutuu

最寄の地下鉄駅 :

半藏門線·神保町駅 (A)

東西線·竹㢦駅 (1 b)

東西線·九段下駅 (出口 6) より徒歩数分

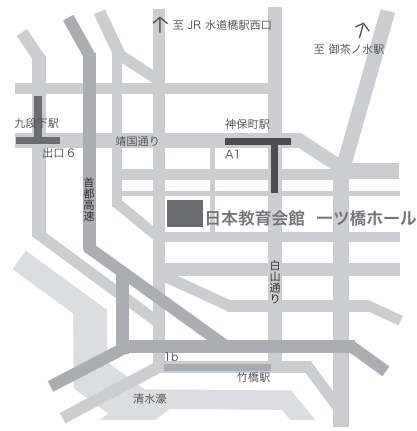

連絡先:

日本音楽療法学会 (JMTA) http://www.jmta.jp 国際交流委員会委員長 佐治順子ｓajin@myu.ac.jp>

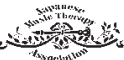

図 3 アジア音楽療法シンポジウムのポスター（日本語版） 
士 (SP), 作業療法士 (OT) などがある. MT は医学, 医 療, 音楽, 教育・福祉, 臨床実践の十分な知識と経験を 有している. かつて, 聖路加国際病院の日野原重明氏の 尽力により, 理学療法士は学会認定から国家資格となっ た．氏が理事長を務める日本音楽療法学会では，音楽療 法士の国家資格化に向けて活動を継続している.

近年，音楽療法への関心や期待が高まり，音楽療法士 を志す人が増えている. 日本音楽療法学会認定の音楽療 法士は現在 1631 名（2009 年 3 月）までになった。 ほか に，全国音楽療法士養成協議会による 1 種，2種の音楽 療法士や，地方自治体が独自に認定した音楽療法士など も誕生している.

最近の動向として，アジア地区の音楽療法シンポジウ ムが開催されたので簡潔に紹介したい. 日本音楽療法学
会国際交流委員会がアジア 23 か国中の6力国からパネリ ストらを迎えて，2009年 3 月に東京で開催し，成功裏に 終えた（図 3，4）。本シンポジウムで各国から発表され た音楽療法士の実践事情や，音楽療法士育成のための教

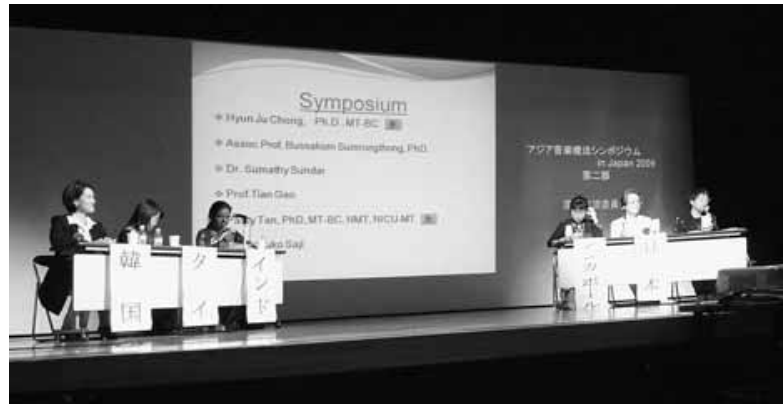

図 4 アジア音楽療法シンポジウム（第二部）

表 7 アジア 6 カ国の音楽療法実践

\begin{tabular}{|c|c|c|c|}
\hline 国名 & 学会・協会 & 認定制度 & MT 数 \\
\hline 1 韓国 & $\begin{array}{l}\text { 韓国音楽療法学会 } \\
\text { 韓国音楽療法教育学会 } \\
\text { 音楽療法臨床応用学会 }\end{array}$ & $\begin{array}{l}\text { 学会発行 } \\
\text { 大学発行 } \\
\text { 生涯教育発行 }\end{array}$ & 693 名 \\
\hline 2 タイ & $x$ & $x$ & 2 又は 3 名 \\
\hline 3 インド & $\begin{array}{l}\text { ナーダ音楽療法センター（25名） } \\
\text { 音楽療法トラスト（10名） }\end{array}$ & $x$ & $\begin{array}{l}50 \text { 名 } \\
\text { (海外認定 } 2 \text { 名) }\end{array}$ \\
\hline 4 中国 & $\begin{array}{l}1989 \text { 年 } \\
\text { 中国専門療法協会（200 名） } \\
2007 \text { 年 } \\
\text { 香港音楽療法協会（12 名） } \\
1996 \text { 年 } \\
\text { 台湾音楽療法協会（24 名） }\end{array}$ & $\begin{array}{l}2006 \text { 年 } \\
\text { 台南芸術大学 }\end{array}$ & $\begin{array}{l}2008 \text { 年 } 80 \text { 名 } \\
\text { 香港（12 名） } \\
\text { 台湾（24 名） }\end{array}$ \\
\hline 5 シンガポール & シンガポール音楽療法学会 (13 名) & $x$ & 13 名 \\
\hline 6 日本 & 日本音楽療法学会 & $\begin{array}{l}\text { 学会 } \\
\text { 自治体・協議会 }\end{array}$ & 1631 名 \\
\hline
\end{tabular}

佐治順子．アジア音楽療法シンポジュウム，発表資料， 2009 .

表 8 アジア 6 カ国に打ける音楽療法教育

\begin{tabular}{|c|c|c|c|}
\hline 国名 & 教育機関 & ガイドライン & \\
\hline 1 韓国 & $\begin{array}{l}\text { 修士 }(9 \text { 校 }) \\
\text { 学士 }(1 \text { 校 })\end{array}$ & $\bigcirc$ & \\
\hline 2 タイ & Rangsit 大学 & $\triangle$ & サブガイドライン \\
\hline 3 インド & $\begin{array}{l}\text { 修士・ディプロマ } \\
\text { (センター, トラスト) } \\
\text { 学士 } \\
(2 \text { 病院, } 1 \text { センター })\end{array}$ & $x$ & \\
\hline 4 中国 & $\begin{array}{l}\text { 中央音楽学院 } \\
\text { 学士 } ・ \text { 修士 } 5 \text { 校 } \\
(2 / 5 \text { 大学 MT 教師 })\end{array}$ & $\begin{array}{l}\text { テンプル大学方式 } \\
500 \text { 名学生 }\end{array}$ & $\begin{array}{c}1989 \text { 中国音楽学院創設 } \\
1990 \text { 年代 失速 閉鎖 } \\
2007 \text { 中国専門音楽療法 } \\
\text { 土協会設立 }\end{array}$ \\
\hline 5 シンガポール & 2 校の芸術大学 & $\times$ & \\
\hline 6 日本 & $\begin{array}{l}\text { 大学・短大 } \cdot \text { 専門学校 } \\
(26) \text { 校・大学院 }\end{array}$ & O & JMTA 資格認定校 26 \\
\hline
\end{tabular}

佐治順子．アジア音楽療法シンポジュウム，発表資料， 2009 . 
育環境などを比較対照し，日本代表のパネリスト佐治が 提示したので，参考にされたい（表 7，8）。一方，世界 の音楽療法を概観すると, 臨床実践や教育・研究におけて も米国や欧州がリードし，オーストラリアや日本などは スタートが遅れた。 しかし，本集会でも明らかになった が23), アジア地域では, 日本や韓国が今後も指導的役割 を演じていくことになるであろら。

\section{おわりに}

本稿では, 最新の音楽療法の現状に加え, 療法効果に 対する評価についても概説した．以上のょらに，音楽療 法に拈ける評価法は, 補完代替医療の他領域にも適用す ることができ，役立つであろら。つまり，適切な目標の 設定，観察しらるマーカーの同定と測定方法，結果の入 手法, 考察の切り口, 将来に対する方向性の設定などを 考慮しなければいけない。

以上に示した各種の評価法により，音楽療法の領域で も, 補完代替医療の各種の療法に拈いても, エビデンス を重ねていくことができるものと考えられる.

\section{参 考 文 献}

1) Bando H. Music Therapy and Internal Medicine. Asian Journal of Med 2001; 44(1): 30-35.

2) 板東 浩. Dr. 板東の音楽療法シリーズ. 入門編. 東京. メ ディカル情報サービス．2009.

3) 佐治順子. 認知性高齢者の音楽療法に関する基礎的研究, 平成 17 年度科研費補助金（研究経過公開促進費）。風間書 房. 2006.

4) http://www.jmta.jp/

5) Podolsky E. Music Therapy. New York. Philosophical Library. 1954.

6) 内閣府. 平成 20 年版高齢社会白書. 1 高齢化の現状と将来 像. http://www8.cao.go.jp/kourei/whitepaper/w-2008/zenbun/ 20index.html

7) 大塚俊男. 日本に抢浽る痴呆性老人数の将来推計. 日精協
誌. 2001; 20(6): 65-69.

8) 森岡由紀. 実際に使える曲目集. 第 7 章音楽療法音楽技術 歌唱全般. 笠嶋道子・吉川武彦監修. 音楽療法. クオリ ティケア. 2009; 187-190.

9) 川島隆太. 高次機能のプレイン・イメージ．神経心理学コ レクション. 医学書院. 2002.

10）板東 浩. 癒しの音楽を考元る. 日野原重明, 篠田知璋編. 新しい音楽療法. 音楽之友社. 2001; 77-93.

11) 佐治順子. 認知性高齢者の音楽療法.認知症のリハビリテー ション実践マニュアル．全日本病院出版社． 2005; :66-79.

12) 松井紀和. 方法と評価. 桜林仁監修. 音楽療法研究第一線 からの報告. 音楽の友社. 1996; 41-80.

13) 北本福美. 老いの心と向き合う音楽療法. 音楽の友社. 2002 ; 104-115.

14）岡崎香奈, 門間陽子．記録と評価を考える一高齢者集団音 楽療法モデル評価表一. 東京音楽療法協会第 4 回音楽療法 講習会資料. 1993; 13-18.

15）赤星建彦, 赤星多賀子, 加藤みゆき. 痴呆老人に対する療 育音楽評価表と機能評価. 高齢者・痴呆性老人のための療 育・音楽療法プログラム。音楽之友社. 1996; 11-28.

16）佐治順子他. パーキンソン病患者の音楽療法効果. 日本神 経治療学会学術大会. 2007.

17) 佐治順子, 佐治量哉. 認知症高齢者の音楽療法. Monthly book medical rehabilitation. 2005; 54: 66-79.

18) 福井 一, 豊島久美子. 音源及び音楽嗜好が内分泌変化に 及汸す影響. 日本音楽療法学会誌. 2004; 4(2): 168-180

19) 吉岡明代，板東 浩，吉岡稔人. 音楽経験がエゴグラムの 改善に与える影響. 日本音楽療法学会誌. 2004; 4(2): 191197.

20) 渡辺智行，福田博美，宮尾 克. 痴呆性高齢者に対する音 楽療法に関するシステマティックレビュー. 愛知教育大学 研究報告. 2005; 54: 57-61.

21) Lai HL, Good M. Music improves sleep quality in older adults. J Adv Nurs 2005; 49(3): 234-244.

22) Clark M, Isaacks-Downton $\mathrm{G}$, Wells $\mathrm{N}$, et al. Use of preferred music to reduce emotional distress and symptom activity during radiation therapy. J Music Ther 2006; 43(3): 247-265.

23）アジア音楽療法・シンポジュウム（東京）in 2009. 2008 年 度日本音楽療法学会主催研修講習会資料. 日本音楽療法学 会. 2009 . 


\begin{abstract}
Evaluation in the Music Therapy

\author{
Hiroshi BANDO ${ }^{1}$, Nobuko SAJI ${ }^{2}$ \\ ${ }^{1}$ Japanese Music Therapy Association, representative, the member of the International Committee
}

${ }^{2}$ Japanese Music Therapy Association, executive board, the chairman of the International Committee
\end{abstract}

Music therapy(MT) is generally classified into recreational MT in broad sense and therapeutic MT in the narrow meaning. In the latter cases, observing and evaluating the case is necessary. The MT sessions are held rather common for the aged people. We must set a long-term goal in response to the cases; to prevent the reducing mental/physical function and to avoid dementia for the healthy people, to maintain/improve the various functions for the patients with dementia and cerebral vascular accident (CVA), to aim the advancement of QOL for the patients with severe status or in the palliative care. Various evaluating methods are seen: Bando proposed 20 items including sensation, behavior and ADL/QOL; Saji proposed 10 items including activity, persistence, cooperation, emotion, intelligence, singing/playing, handling, walking, smooth action, verbal response. Matsui summarized general MT diagnostic table and MT evaluation table for the aged, and other methods by Kitamoto (Utatsuyama), Okazaki/ Monma, and Akaboshi are seen. The number of the music therapists registered by Japanese Music Therapy Association is increasing, and $1^{\text {st }}$ Asian International Symposium of Music Therapy was held in March 2009. Thus, MT has become more important in Complementary and Alternative Medicine (CAM).

Key words: music therapy, evaluation, music therapist, Asian International Symposium, Complementary and Alternative Medicine (CAM) 